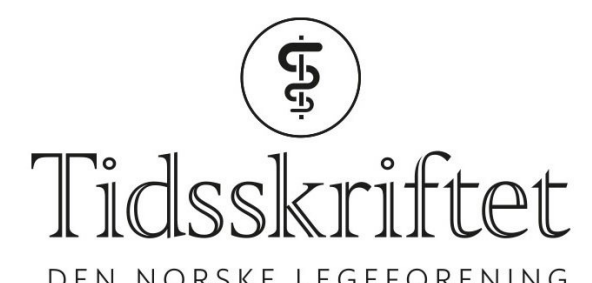

DEN NORSKE LEGEFORENING

\title{
Sterk formidler av viktig kunnskap
}

ANMELDELSER

PRABA ARULANANDAM

Fastlege, Mortensrud Medisinske Senter

Oslo

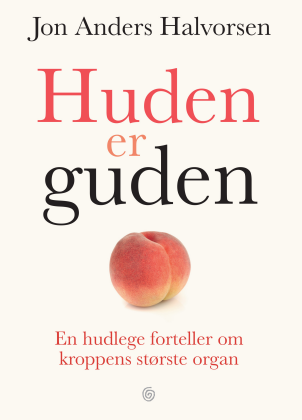

Jon Anders Halvorsen

Huden er guden

364 s, ill. Oslo: Kagge Forlag, 2018. Pris NOK 399

ISBN 978-82-489-2227-8

Huden er guden er litterær sakprosa som også kan betegnes som brukslitteratur. Spesialist i hudsykdommer Jon Anders Halvorsen tar oss med på en reise fra eggcellens befruktning, gjennom fosterstadiets utvikling og til hvordan og hvorfor huden fungerer. Vi får høre om symbioseforhold og samspill med andre viktige organer samt et historisk innblikk i hvorfor menneskekroppen er som den er.

Innledningsvis presenteres nysgjerrighetsvekkende refleksjoner rundt viktigheten av hud, hvorfor vi er skapt med hud og hvorfor det er så viktig å ta vare på den. Videre tar forfatteren oss med inn i hvordan huden dannes og hvordan den er bygd opp.

I sindige og folkelige ordelag fors $ø$ ker forfatteren å la leserne forstå. Hvordan man forstår innledningen, er essensielt for videre forståelse av tematikken.

Boken inneholder flere småtoppede høydepunkter. Vi får klarhet i historiske myter, hvorfor og hvordan enkelte diagnoser har fått sine navn, og hvor ny forskning og oldtidens myter har møttes og banet vei for dagens behandlingsmodeller. I en jungel av diagnoser forsøker man å forenkle disse aspektene for leseren.

Til slutt får vi en gjennomgang av hudens normale funksjon i alle livets stadier samt sykdommer ut fra kroppens kronologiske alder. Avslutningen er imidlertid noe brå. 
Boken er oversiktlig og lettlest og uten krav til spesielle grunnkunnskaper. Likevel kan enkelte temaer være utfordrende å forstå, spesielt for unge lesere. Språket er forholdsvis enkelt, tatt i betraktning hvor mange temaer man er innom og diagnoser som blir omtalt. Medisinske betegnelser er ofte satt i parentes, slik at lesere som vil finne foto, eller ytterligere informasjon, kan finne frem til dette.

Forfatterens egne erfaringer gjennom mange år som hudlege er bokens styrke. Man ser lett at forfatteren besitter god faglig og historisk kunnskap. Han går inngående gjennom fysiologiske prosesser i all slags typer hud. Ulike etnisiteters hud forklares, ikke bare den hvite huden, men også den mørke, lysbrune og brune hud. Skjønnhetsbehandlinger og nymotens behandling med laser, botox og «fillers» tas opp på en opplysende måte, uten å stigmatisere.

Boken er skrevet for et bredt allment publikum og passer såvel til fine frognerfruer som til sterke rørleggere.

Etter å ha reflektert rundt bokens innhold er jeg faktisk enig - huden er guden!

Publisert: 25. mars 2019. Tidsskr Nor Legeforen. DOI: 10.4045/tidsskr.19.0024

(C) Tidsskrift for Den norske legeforening 2020. Lastet ned fra tidsskriftet.no 